\begin{tabular}{|c|c|c|}
\hline institute & $\begin{array}{l}\text { CARADDE: Jurnal Pengabdian Kepada Masyarakat } \\
\text { https://journal.ilininstitute.com/index.php/caradde } \\
\text { Volume } 1 \text { | Nomor } 2 \text { | Februari | } 2019 \\
\text { e-ISSN: } 2621-7910 \text { dan p-ISSN: } 2621-7961 \\
\text { DOI: https://doi.org/10.31960/caradde.v1i2.107 }\end{array}$ & $\begin{array}{l}\text { Coin } \\
\text { caradoE }\end{array}$ \\
\hline
\end{tabular}

\title{
Analisis Harga Jual dan Strategi Penjualan Produk Es Krim di UKM Gelali Kecamatan Sukun Kota Malang
}

\author{
Muhammad Arif Kamal ${ }^{1}$, Miftakhurrizal Kurniawan ${ }^{2}$, Suprayogi ${ }^{3}$, Imam Santoso ${ }^{4}$, \\ Wignyanto $^{5}$
}

\begin{tabular}{ll}
\hline \hline Keywords: & Abstrak. UKM Gelali berpartisipasi dalam kegiatan \\
UKM Gelali; & pengabdian masyarakat dengan tujuan memperbaiki kualitas \\
Es Krim; & $\begin{array}{l}\text { produk, proses produksi, desain kemasan dan merk serta } \\
\text { persyaratan administrasi penting lainnya termasuk perizinan }\end{array}$ \\
Efisiensi produksi. & usaha agar produknya dapat diterima oleh konsumen. Metode \\
& pendekatan yang digunakan dalam kegiatan pengabdian \\
Corespondensi Author & kepada masyarakat ini adalah 1. identifikasi kondisi unit \\
Jurusan Teknologi Industri & usaha, 2. Pelatihan, penyuluhan, dan pembimbingan teknis. \\
Pertanian, Fakultas Teknologi & Hasil dari kegiatan ini adalah efisiensi produksi (kuantitas dan \\
Pertanian, Universitas Brawijaya & kualitas) dengan perbaikan manajemen pengolahan yang ada, \\
Jl. Veteran Malang & adanya pemberdayaan ekonomi masyarakat melalui \\
Email: m.arif.kamal@ub.ac.id & pengembangan agroindustri pengolahan susu menjadi es krim \\
& sehingga akan meningkatkan kesejahteraan masyarakat di \\
History Artikel & lingkungan UKM Es Krim Gelali.
\end{tabular}

Reviewed: Desember-2018

Accepted: Januari-2019

Published: Februari-2019

This work is licensed under a Creative Commons Attribution

4.0 International License

\section{PENDAHULUAN}

Pertumbuhan kuliner di Malang Raya terbilang cukup pesat dan sukses. Beragam bidang kuliner memiliki segmentasi pasar masing-masing, mulai dari makanan hingga minuman. Salah satu bidang kuliner yang memiliki segmentasi pasar yang luas adalah es krim. Meskipun beberapa produsen es krim didominasi oleh perusahaan besar, namun terdapat beberapa industi rumahan yang mulai membidik usaha es krim tersebut. Perkembangan usaha rumahan yang semakin banyak memerlukan pembinaan dan pelatihan yang berorientasi nilai tambah untuk meningkatkan daya saing (Setiawan, 2012).

Salah satu UKM yang memproduksi es krim di Kota Malang adalah UKM Gelali. Sebagai entitas bisnis pada skala UKM, permasalahan umum yang dihadapai usaha ini adalah permasalahan klasik seperti modal, serta permasalahan lain seperti administrasi keuangan dan keterbatasan sarana prasarana (Lestari, 2010). Permasalahan yang dihadapi oleh UKM Gelali diantaranya masih rendahnya tingkat implementasi manajemen pengolahan dan pengemasan, strategi pemasaran, administrasi keuangan, serta standar penggunaan bahan tambahan pangan aditif yang aman untuk produk es krim.

Permasalahan mendasar pada kegiatan produksi pada UKM ini adalah cara produksi yang sederhana, konvensional dan peralatan seadanya sehingga mempengaruhi kuantitas serta kualitas produksi. UKM Gelali 
Belum mempunyai sarana pendingin yang terpisah dari penggunaaan rumah tangga. Pengemasan es krim yang dilakukan ini dilakukan seadanya sehingga berdampak pada tampilan dan kualitas kemasan yang kurang menarik (marketable). Untuk mengatasi permasalahan tersebut diperlukan pendampingan proses produksi, tatacara pengolahan yang baik dan benar serta perbaikan desain kemasan yang meliputi logo, label, dan penambahan peralatan penunjang produksi. Menurut Atalay et al (2013), perbaikan cara produksi diharapkan dapat meningkatkan kualitas produk dan peningkatan jumlah produksi. Sedangkan desain kemasan yang menarik diharapkan dapat meningkatkan daya simpan produk dan juga meningkatkan daya saing es krim dipasaran. Penambahan peratalatan produksi diharapkan dapat meningkatkan kapasitas produksi dan kualitas produk.

Berdasarkan uraian permasalahan di atas, maka tujuan kegiatan pengabdian kepada masyarakat pada UKM Gelali ini adalah: (1) Mendukung peningkatan daya saing usaha kuliner khususnya di bidang es krim, karena memiliki pasar yang sangat potensial. (2) Meningkatkan pemahaman tentang teknologi pengolahan susu menjadi produk es krim yang memiliki nilai tambah. (3) Memberikan bantuan alih teknologi Teknologi Tepat Guna untuk usaha skala rumah tangga sehingga bisa meningkatkan produksi dan kualitas produk. Peningkatan mutu produk dan perluasan pemasaran. (5) Sosialiasi dan diseminasi Teknologi Tepat Guna di tingkat pengrajin atau UKM berupa alih teknologi peralatan produksi yang bisa meningkatkan kapasitas produksi dan performa produk.

\section{METODE}

Metode pendekatan yang digunakan
dalam kegiatan pengabdian kepada
masyarakat ini adalah: (1) Identifikasi kondisi
unit usaha. mitra dilakukan untuk
mengetahui keadaan usaha mitra. Pendekatan
yang dilakukan pada identifikasi ini dilakukan
dengan survei lokasi usaha serta melakukan
wawancara dengan pelaku usaha. Pendekatan
ini dilakukan untuk mengidentifikasi
permasalahan yang ada di UKM,

menganalisa permasalahan dan menawarkan strategi penanganan masalah (Jumiati dkk, 2015). (2) Pelatihan, penyuluhan, dan pendampingan teknis dengan cara memberikan materi pelatihan teknologi dan manajemen industri dalam rangka perbaikan manajemen usaha dan pemanfaatan teknologi.

\section{HASIL DAN PEMBAHASAN}

Hasil dari kegiatan pengabdian masyarakat ini meliputi identifikasi usaha dari sisi pemasaran meliputi strategi pemasaran yang digunakan, target konsumen dan posisi produk. Selanjutnya dilakukan analisis permasalahan usaha yang dapat dijadikan dasar untuk melakukan analisis SWOT yang meliputi kekuatan (strength), kelemahan (weakness), peluang (opportunity) dan ancaman (threat). Menurut Çakır dan Balagtas (2014), pada aspek usaha perlu dilakukan juga analisis usaha untuk menentukan harga jual yang tepat. Selain itu juga dilakukan perbaikan proses produksi, pengemasan dan inovasi produk agar produk yang dihasilkan dapat memenuhi kebutuhan dan selera konsumen,serta memperluas jangkauan pemasaran.

\section{Hasil Identifikasi Kondisi Unit Usaha}

Usaha yang dijalankan oleh UKM Gelali tergolong masih sangat baru, karena belum berusia 1 tahun. Oleh karena itu, UKM tersebut harus menyusun strategi pemasaran yang baik agar usaha yang dijalankan dapat berjalan secara berkelanjutan (Waziiroh dkk, 2017). Strategi pemasaran tersebut meliputi aspek segmen pasar yang dituju, target konsumen dan posisi produk terhadap produk sejenis yang sudah ada di pasaran.

\section{a. Strategi Pemasaran}

1) Segmenting, Menurut Sugiyanto (2017), strategi ini mengelompokan segmentasi pasar menjadi beberapa kelompok yaitu kelompok menurut jenis kelamin, kelompok jenis usia, kelompok jenis hasil pendapatan (pekerjaan). Dari hasil analisa unit usaha didapatkan bahwasanya produk es krim yang di produksi, relevan dengan segementasi pasar dari umur 7 
Kamal, Kurniawan, Suprayogi, Santoso, Wignyanto. Analisis Harga dan Strategi Penjualan

tahun hingga 35 tahun, dengan jenis kelamin perempuan (yang menjadi target utama), dan memiliki pekerjaan sebagai pelajar dan wiraswasta.

2) Targetting, Menurut Nasution dkk (2017), strategi ini adalah hasil turunan dari strategi segmenting yang merupakan prospek pasar secara luas. Strategi ini lebih spesifik karena mengelompokkan segementasi pasar menjadi beberapa kelompok yang meliputi target utama (hot prospect hinggan low prospect). Berdasarkan analisa pengolahan data yang telah dilakukan, bahwasanya target utama dari pemasaran es krim adalah mahasiswa perempuan dengan rentan umur 19-23 tahun. Hal ini didasari oleh banyaknya mahasiswa di lingkungan sekitar unit usaha. Sehingga berpotensi besar untuk meningkatkan omzet penjualan es krim.

3) Positioning, Menurut Santoso dkk (2017), strategi ini adalah strategi yang dilakukan setelah mendapatkan target pasar yang potensial. Inovasi kemasan dan produk yang dilakukan akan menambah daya jual dan menjadikan produk es krim dari unit usaha ini mendapatkan tempat diprespektif masyarakat. Positioning yang akan dilakukan adalah dengan membuat es krim home made yang bebas dari pengawet dan memiliki harga yang terjangkau oleh target pasar dengan keunikan produk yang ditawarkan. Sehingga dengan adanya strategi ini akan dapat bertahan dari persaingan es krim yang sudah ada di pasaran.

\section{b. Strategi SWOT}

Selain strategi pemasaran yang telah didefinisikan di atas, UKM Gelali perlu mengenali potensi dan peluang, kekuatan, tantangan dan kelemahan dari produk yang diproduksi. Hal ini sangat diperlukan agar UKM Gelali mampu menerapkan strategi pemasaran yang telah di definisikan

\section{c. Perhitungan Biaya Produksi Es Krim}

Perhitungan biaya produksi menjadi salah satu bagian penting dalam menentukan harga jual produk es krim (Heldman and sebelumnya dengan lebih baik. Hasil analisis tersebut adalah sebagai berikut:

\section{Kekuatan (Strength)}

- Es krim home made

- Target yang terjangkau

- Produk unik (karena sudah di inovasi dengan penambahan ekstrak strawberry)

- Harga yang terjangkau

\section{Kelemahan (Weakness)}

- Produk ini baru di pasar

- Belum banyak yang mengenal produk es krim ini

- Belum memiliki izin usaha

\section{Peluang (Opportunit)}

- Pasar es krim sangat besar dan luas

- Pemasaran digital menjadi peluang untuk mempromosikan produk es krim

- Produk memiliki inovasi yang potensial untuk kedepannya

Lokasi unit usaha yang berdekatan dengan hot prospect

\section{Ancaman (Threat)}

- Pasar es krim memiliki banyak pesaing

- Produk home made, sehingga memiliki masa simpan yang relatif pendek dan alat produksi yang kurang mendukung

Awal mula pendirian es krim rumahan ini berawal dari reseller es krim yang diambil dari pabrik es krim yang kemudian dijual kepada warga sekitar rumah. Media penjualan yang masih terbilang konvensional menjadi kendala untuk menambah daya saing produk es krim. Produk belum memiliki nama merek untuk dagang. Peralatan yang digunakan juga tergolong kurang memadai untuk menunjang proses produksi. Proses produksi yang dilakukan selama ini memiliki kapasitas yang kecil, padahal produk ini memiliki potensi yang sangat besar di pasar. Harga produk yang murah dengan margin profit diatas $50 \%$ lebih menjadikan potensi tersendiri bagi produk es krim home made ini.

Daryl, 2016). Pada perhitungan biaya produksi digunakan pendekatan biaya untuk pembuatan 20 cup es krim (Biaya Habis Pakai) dapat dilihat pada Tabel 1. Berikut 
Caradde: Jurnal Pengabdian Kepada Masyarakat

Vol 1 No 2, Februari 2019

Tabel 1. Perhitungan Biaya Produksi

\begin{tabular}{clcr}
\hline No. & Nama Barang & Jumlah Barang & $\begin{array}{c}\text { Jumlah } \\
\text { (Rp) }\end{array}$ \\
\hline 1 & Susu & $500 \mathrm{ml}$ & 3.500 \\
2 & Gula & $50-75$ gram & 3.000 \\
3 & Tepung Maizena & $20-50$ gram & 1.000 \\
4 & Perasa (Coklat, strawberry, milo) & $30-45$ gram & 4.500 \\
5 & SP (Pengembang) & 20 gram & 500 \\
6 & Kemasan + sendok & 1 kemasan (20 & 4.000 \\
& & Cup) & \\
7 & Listrik untuk mixer & 30 watt (15 menit) & 1.000 \\
8 & Listrik untuk freezer & 200 watt (2-3 jam) & 2.000 \\
9 & Gas untuk memasak & $5-7$ menit & 1.000 \\
\hline & Total & & $\mathbf{2 0 . 5 0 0}$ \\
\hline
\end{tabular}

d. Harga Pokok Produksi (HPP) Produk Es Krim

Berdasarakan perhitungan biaya produksi di atas, maka dilakukan perhitungan harga pokok produksi sebagai berikut :

$$
\begin{aligned}
\mathrm{HPP} & =\frac{\text { Total Biaya Produksi }}{\text { Jumlah Produk }} \\
& =\frac{20.500}{20 \text { Kemasan Cup }} \\
& =\text { Rp. } 1.025,00
\end{aligned}
$$

Berdasarkan hasil analisa di atas, maka harga pokok produksi es krim adalah sebesar Rp. 1.025,00

e. Harga Jual Es Krim

Harga jual es krim = Rp. 2000/cup

\section{f. Keuntungan}

Keuntungan

$$
\begin{aligned}
= & \text { Harga jual }-\mathrm{HPP} \\
= & \text { Rp. } 2 \cdot 000,00 \\
& - \text { Rp. } 1 \cdot 025,00 \\
= & \text { Rp. } 975,00
\end{aligned}
$$

\section{Hasil Pelatihan dan Pendampingan}

Tujuan akhir kegiatan pengabdian masyarakat pada UKM Gelali adalah adanya perbaikan proses produksi dan inovasi produk yang secara rinci dijelaskan sebagai berikut:

\section{a. Perbaikan proses produksi}

Bahan baku utama pembuatan es krim adalah susu kental manis dan air. Sedangkan bahan tambahan yang digunakan adalah tepung maizena dan gula pasir sebanyak 3 sendok untuk setiap $500 \mathrm{ml}$ air. Susu kental manis yang digunakan adalah sebanyak 3 bungkus atau sekitar 450-500 $\mathrm{ml}$. Secara umum, Menurut Hartatie (2011), proses produksi es-krim secara sederhana dapat dilihat pada Gambar 5. di bawah ini.

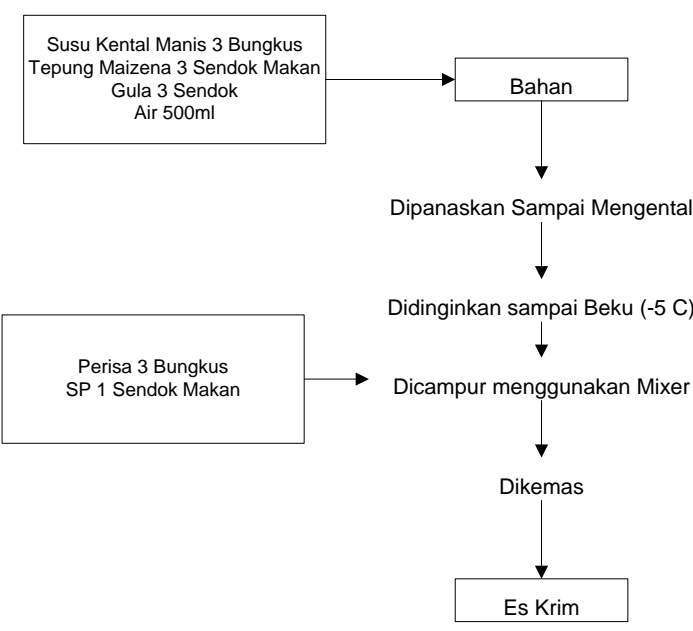

Gambar 5. Diagram Alir Pembuatan Es Krim

Selama ini perlatan produksi masih menggunakan peralatan sederhana dan seadanya. Melalui kegiatan pengabdian ini diberikan peralatan yang dapat mempercepat proses produksi serta meningkatkan kapasitas produksi. Peralatan tersebut antara lain mesin pengaduk adonan (mixer) dan mesin pendingin (Cool Box) dengan kapasitas $100 \mathrm{~L}$. Peralatan produksi tersebut dapat dilihat pada Gambar 6. di bawah ini. 
Kamal, Kurniawan, Suprayogi, Santoso, Wignyanto. Analisis Harga dan Strategi Penjualan

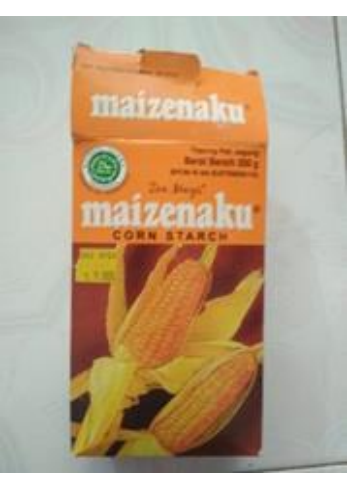

(a) Tepung Maizena

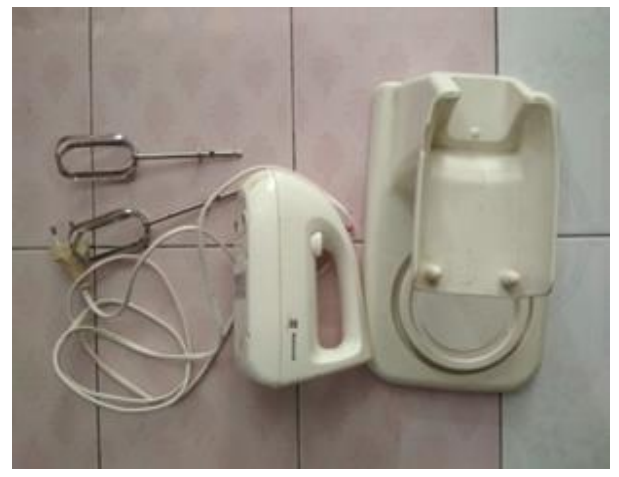

(b) Mixer

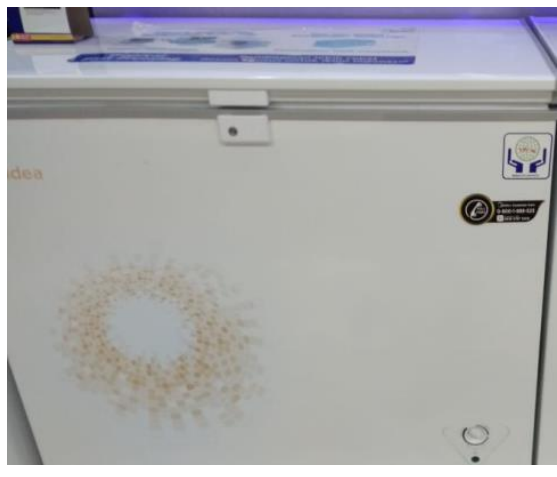

(c) Freezer Box

Gambar 6. Bahan dan Peralatan tambahan untuk perbaikan proses produksi

\section{b. Inovasi Produk}

Berdasarkan analisa dari unit usaha es krim inovasi yang ditawarkan adalah dari aspek kemasan dan produk es krim. Kemasan es krim dari unit usaha ini sebelumnya belum memiliki merek atau logo, sehingga konsumen akan sulit untuk mengenali produk es krim ini, sehingga kami mengusulkan untuk menambah logo dan merek sebagai atribut kemasan es krim. Inovasi yang kedua adalah dengan menambahan ekstrak buah

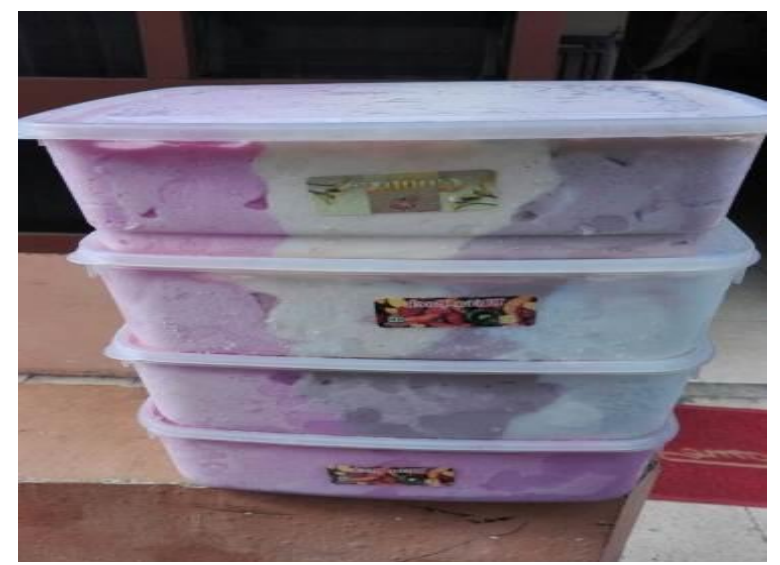

Gambar 7. Produk belum memiliki merek atau logo strawberry kedalam adonan es krim. Penambahan eksrtak ini bertujuan untuk menjadikan es krim ini unik dan berbeda dari es krim ada umumnya yang beredar di pasaran (Oktavia dan Esti, 2014). Menurut Tiarani (2015), ekstrak strawberry ini mengandung polifenol yang memiliki kemampuan mencegah air dan minyak untuk terpisah, sehingga es krim yang mengandung cairan tersebut bisa mempertahankan bentuk aslinya lebih lama dan sulit mencair.

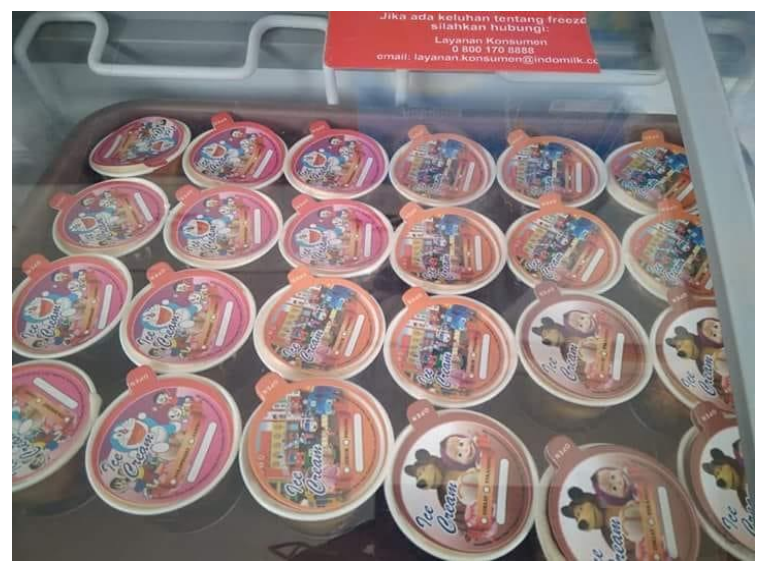

Gambar 8. Produk sudah memiliki merek atau logo 


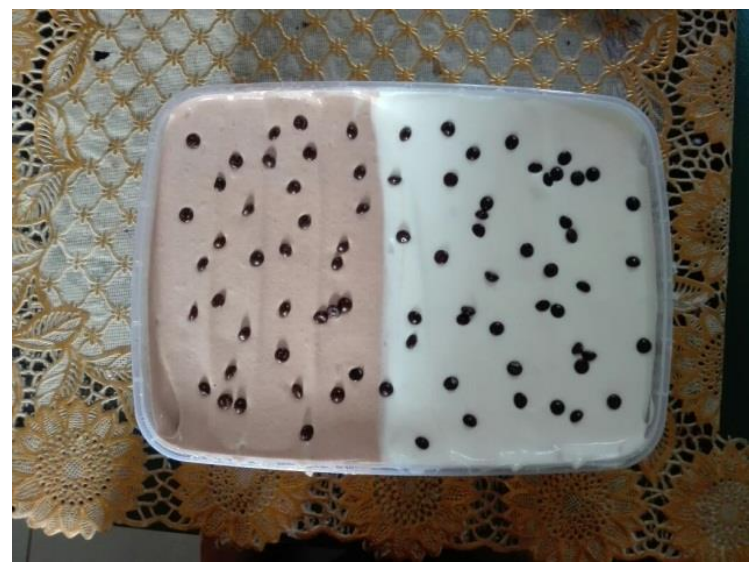

Gambar 9. Sebelum ditambah ekstrak strawbery

\section{SIMPULAN DAN SARAN}

Berdasarkan hasil identifikasi usaha pada UKM Es Krim Gelali diketahui bahwa meskipun UKM tersebut masih tergolong baru, namun mempunyai potensi yang cukup baik dalam pengembanganb usaha ke depan. Agar tujuan tersebut dapat tercapai, maka UKM Gelali perlu memahami dengan baik strategi pemasaran terkait segmen pasar yang dituju, target konsumen,posisi produk. UKM Gelali juga perlu mempertimbangkan hasil analisis SWOT yang telah dilakukan meliputi aspek kekuatan, kelemahan, tantangan dan ancaman yang dihadapi dalam pemasaran produk es krim yang dihasilkan.

UKM Es Krim Gelali telah mampu menganalisa potensi pasar Es Krim di wilayahnya dan mampu memberikan diversifikasi produk dan nilai tambah olahan susu yaitu dalam bentuk produk Es Krim. Teknologi pengolahan susu menjadi es krim juga telah dipahami dengan baik dan sangat membantu dalam proses produksi Es Krim yang lebih baik. Pihak UKM juga sangat cepat dalam merespon permintaan pasar dengan memanfaatkan bantuan berupa alih teknologi dan bantuan peralatan mesin pendingin dan mesin pengaduk untuk meningkatkan kapasitas produksi dan penyimpanan produk. UKM Gelali juga telah merespon permintaan konsumen dengan membuat desain kemasan yang lebih baik dengan nama dan logo yang lebih baik.

UKM Es Krim Gelali juga sangat antusias dengan adanya inovasi produk yang dicoba dalam proses produksi. Hal ini akan

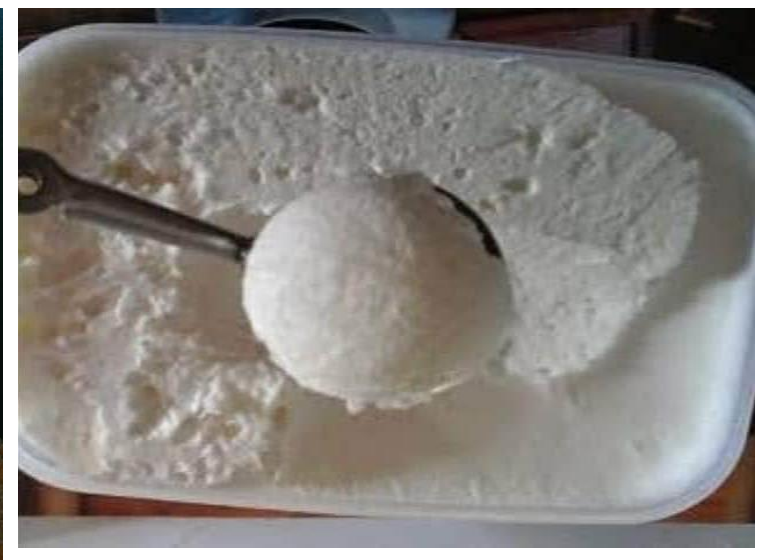

Gambar 10. Setelah ditambah ekstrak strawbery

menambah mutu produk es krim yang dihasilkan dan diharapkan dapat bersaing dengan produk sejenis.Salah satu bentuk inovasi yang unik adalah adalah dengan menambahan ekstrak buah strawberry ke dalam adonan es krim. Penambahan eksrtak ini bertujuan untuk menjadikan es krim ini unik dan berbeda dari es krim ada umumnya yang beredar di pasaran. Ekstrak strawberry ini mengandung polifenol yang memiliki kemampuan mencegah air dan minyak untuk terpisah, sehingga es krim yang mengandung cairan tersebut bisa mempertahankan bentuk aslinya lebih lama dan sulit mencair.

Adapun saran yang perlu dipertimbangkan dalam pemasaran produk es krim pada UKM Gelali adalah : (1) perlu melengkapi persyaratan administrasi dan pengurusan ijin edar, agar dapat dipasarkan lebih luas serta (2) perlu melakukan kerjasama jejaring pemasaran dan pemsasran online agar produk yang dihasilkan lebih dikenal masyarakat.

\section{DAFTAR RUJUKAN}

Atalay, M., N. Anafartand., F. Sarvan. 2013. The relationship Between Innovation And Firm Performance: An Empirical Evidence From Turkish Automotive Supplier Industry. Procedia-Social and Behavioral Sciences 75 : 226-235.

Ayed, C., Sara I.F.S., Ann-Marie W, dan Elisabeth G. 2017. Understanding Fat, 
Kamal, Kurniawan, Suprayogi, Santoso, Wignyanto. Analisis Harga dan Strategi Penjualan

Proteins And Saliva Impact On Aroma Release From flavoured Ice Creams. Journal of Food Chemistry 267 (1) : 132-139.

Çakır, M dan J. V. Balagtas. 2014. Consumer Response to Package Downsizing: Evidence from the Chicago Ice Cream Market. Journal of Retailing 90 (1) : 1-12.

Hartatie, E.S. 2011. Kajian Formulasi ( Bahan Baku , Bahan Pemantap ) Dan Metode Pembuatan Terhadap Kualitas Es Krim. Jurnal GAMMA 7(1) : 20-26.

Jumiati., V.S. Johan, dan Yusmarini. 2015. Studi Pembuatan Es Krim Berbasis Santan Kelapa Dan Bubur Ubi Jalar Ungu. Jurnal JOM Faperta 2(2) : 1-12.

Lestari E.P. 2010. Penguatan Ekonomi Industri Kecil Dan Menengah Melalui Platform Klaster Industri. Jurnal Organisasi dan Manajemen, 6(2) : 146157.

Nasution, M.I., Muhammad A.P., Satria M.A.N. 2017. Pembinaan Pengelolaan Manajemen Usaha dan E-Marketing Pada Pelaku Usaha Industri Mikro Pengrajin Sepatu di Kecamatan Medan Denai. Jurnal Pengabdian Kepada Masyarakat. 23(2) : 292-299.

Oktavia, A., C. Anam, dan Esti Widowati. 2014. Pengaruh Perlakuan Penambahan Ekstrak Dan Puree Wortel (Daucus Carota L.) Pada Teknologi Produksi Chili Cream Cheese: Kajian Rendemen, Ph, Lemak, Betakaroten, Aktivitas Antioksidan Dan Sensori. Jurnal Teknologi Hasil Pertanian 7(2) : 76-85.
Santoso, D., Indarto., Aprih S. 2017. Pemberdayaan Usaha Kecil Mikro (UKM) Menuju Kemandirian Melalui Pembinaan Kewirausahaan, Pemodalan, dan Pemasaran di Kecamatan Tugu. Jurnal Pengabdian Masyarakat. 8(2) : 166173

Setiawan, Heri. 2012. Pengaruh Orientasi Pasar, Orientasi Tenologi dan Inovasi produk Terhadap Keunggulan Bersaing Usaha Songket Skala Kecil di Kota Palembang. Jurnal Orasi Bisnis Edisi keVIII : 12-19.

Sugiyanto., Aisyatul, K., Auria F.Y. 2017. Peningkatan Ketrampilan Pembuatan Desain Kemasan serta Pemanfaatan Media Promosi dan Pemasaran Online Pada Kube Ash-Shidiqqy dan Pik Abdussalam Jepara. Jurnal Techno.COM. 16(1) : 9-16.

Tiarani, E.A. 2015. Pengaruh Jumlah Ekstrak Angkak ( Red Fermented Rice ) Dan Puree Stroberi Terhadap Sifat Organoleptik Es Krim. E-journal boga 3(1) : 37-45.

Waziiroh, E., Dego Y.S., Nur I. 2017. Proses Termal Pada Pengolahan Pangan. UB Press. Malang. 